\title{
Det singulæres universalisering
}

\section{Om vidnesbyrdets litteratur hos Derrida}

Litteraturen er den mest interessante ting $i$ verden, måske mere interessant end verden.

(Derrida 1992b: 47)

Der findes selvsagt i publikationskronologisk forstand en sen Derrida, men denne sene Derrida udgør ikke i filosofisk, etisk eller politisk forstand en vending, et brud eller en revision af den tidlige. Snarere, vil jeg hævde, er hans tænkning præget af en sammenhængende, fortløbende udvikling eller, måske mere præcist, eksplikation, hvor det tidlige forfatterskabs indsigter og pointer - grammatologien, det strukturalistiske selvopgør, dekonstruktionen af forestillingen om selvnærvær hos Husserl, iagttagelsen af betydningers tilblivelse etc. - udfoldes og finder mere konkret anvendelse i det sene. ${ }^{\mathrm{I} D e}$ indledende dekonstruktive betragtninger appliceres så at sige i senværket, der i højere grad reflekterer over den dekonstruktive tænknings konsekvenser: "Jeg forsøger på min måde at drage nogle etiske, juridiske og politiske konsekvenser, der drejer sig om tiden, gaven, gæstfriheden, tilgivelsen, beslutningen - eller det kommende demokrati," som Derrida selv sagde, da han i 2001 modtog Theodor W. Adorno-prisen af byen Frankfurt (Derrida 2002a: 21). ${ }^{2}$ Heller ikke i Derridas egen forståelse sker der altså en vending: "der har aldrig, som man indimellem påstår, i 1980'erne eller 1990'erne fundet en political turn eller ethical turn af 'dekonstruktionen' sted, i det mindste ikke sådan som jeg har erfaret det." (Derrida 2003: 64). Forestillingen om en vending eller en drejning fordrejer billedet, den vender tænkningen bort fra det, der stadig står tilbage at tænke; tænkningen af det politiske har altid været en tænkning af différancen og tænkningen af différancen også altid en tænkning af det politiske (jf. ibid.) différancen, tænkningen af forskel og udsættelse, er således det, der informerer tænkningen af "det kommende demokrati", la démocratie à venir, der insisterer på en åbenhed i demokratibegrebet, som modarbejder etableringen af en hegemo- 
nisk betydningsdannelse, og uophørligt sætter spørgsmålstegn ved de bestående magtrelationer. ${ }^{3}$

I dette forsøg på at tænke det, der står tilbage - det, der resterer - at tænke, at tænke det, han kalder 'det umuliges mulighed', at tænke tænkning anderledes, dvs. uden for eller forskelligt fra en vestlig nærværsmetafysik, spiller litteraturen en central og gennemgående rolle hos Derrida, idet han, lige som Adorno, i litteraturen, og i kunst i det hele taget, finder en evne til kritisk at decentrere filosofien (jf. Derrida 2002a: 52f.). ${ }^{4}$ Et af de områder, hvor Derridas senværk har afgørende betydning også for litteratur- og kunstvidenskaben, er i forståelsen af vidnesbyrdet, der tager del i en bredere aktuel interesse for forholdet mellem litteratur og etik, eller æstetik og etik, hvad flere omtaler som 'den etiske vending' i humanvidenskaberne - det vil måske sige, at der ikke sker en etisk vending i Jacques Derridas tænkning, men at hans tænkning derimod har været med til at facilitere en mere generel etisk vending i humanvidenskaberne, bort fra vulgær postmoderne relativisme og lignende.

Derridas betydning har blandt andet at gøre med hans påpegning af den intime og komplicerede relation mellem vidnesbyrd og fiktion eller litteratur. Undersøgelsen af denne relation, som det altså hér skal dreje sig om, er viet flere seminarer og forelæsninger og behandles især i tre tekster: Demeure - Maurice Blanchot fra 1998 (oprindeligt et foredrag holdt i 1995), "Le parjure, peut-être" fra 2002 og Poétique et politique du témoignage fra 2005 (oprindeligt publiceret i engelsk oversættelse i 2000), der sætter sig for at bekræfte en - for hans tænkning af vidnesbyrdet i øvrigt gennemgående - hypotese om, at ethvert ansvarligt vidnesbyrd involverer en poetisk erfaring af sproget (jf. Derrida 2005: 9). ${ }^{5}$

Jeg vil her primært tage udgangspunkt i Demeure, der er helliget en læsning af Blanchots enigmatiske selvbiografiske tekst L'instant de ma mort (Mit dødsøjeblik), der udkom i 1994, da Blanchot var 87, og som beskriver nogle begivenheder, der fandt sted 50 år tidligere, under Anden Verdenskrig. ${ }^{6}$ I den kompakte tekst, der blot fylder omkring 12 meget korte sider, 7 genkalder jeg-fortælleren - senere glider teksten over i en tredjepersonsnarration - sig en ung mand, som var tæt på at blive henrettet i Anden Verdenskrigs sidste dage. Hvad der til at begynde med fremstilles som en deling nazistiske soldater hærger Blanchots hjemegn, det vil sige Quain i Bourgogne, ${ }^{8}$ afbrænder gårde og dræber tre bondesønner. Den unge mand beordres sammen med sin familie ud af deres hus, kaldet slottet, og - tilsyneladende på grund af en mistanke om hans deltagelse i modstandsbevægelsen, idet det nævnes, at han har kammerater i makien - hans henrettelsespeloton opstilles og tager sigte, men han reddes i sidste øjeblik, da løjtnanten forstyrres af larmen fra kampe i nærheden. Det viser sig, at soldaterne faktisk er russere fra den forræderiske Vlassov-hær, der havde allieret sig med nazisterne, og en af disse forrædere forræder forræderiet, mens løjtnanten er optaget, idet han lader den unge mand/Maurice Blanchot løbe. Han mister derfor ikke livet, men et manuskript - "som måske indeholdt planer for krigen" (Blanchot: 15) - som soldaterne finder under ransagningen af huset, der i modsætning til de omkringliggende gårde ikke brændes ned. Herefter martres han af "uretfærdighedens tortur", overlevede han alene i kraft af sit tilhørsforhold til en adelig klasse? og lever et posthumt liv. I en art efterskrift berettes det, at han senere 
i Paris mødes med André Malraux og Jean Paulhan og taler om et manuskript, som de forsøger at finde. Teksten slutter med - i en tilbagevenden til førstepersonen - at sige, at det er ligegyldigt, at det eneste blivende ("seul demeure") er følelsen af lethed, af "mit siden da altid forestående dødsøjeblik" (Behrendt: 334), "l'instant de ma mort désormais toujours en instance" (Blanchot: 20).

Flere kommentatorer har bemærket, at Demeure kan ses som et fors $ø g$ fra Derridas side på at rehabilitere Maurice Blanchot politisk og redde sin nære ven og vigtige filosofiske inspirationskildes eftermæle, idet denne - lige som Derridas anden nære ven, Paul de Man - har en omdiskuteret fortid på den yderste højrefløj og før krigen publicerede i de antisemitiske og højrenationalistiske tidsskrifter L'Insurgé og Combat, lige som han under krigen skrev i den kollaborerende Le journal des débats. ${ }^{9} \mathrm{Jeg}$ vil dog ikke gå ind i selve læsningen af Blanchots tekst, men vil i stedet fors $\varnothing$ ge - idet jeg på de næste par sider bevæger mig relativt tæt på Derridas formuleringer - at uddrage nogle af de væsentligste mere principielle pointer, som har generalisérbar betydning for en forståelse af forholdet mellem vidnesbyrd, litteratur og fiktion. ${ }^{\text {Io }}$

Vidnesbyrdet er ifølge Derrida altid autobiografisk. Det beretter i førsteperson den meddelelige og umeddelelige hemmelighed om det, der er hændt mig og mig alene; hvad jeg var i stand til at erfare, se, høre, mærke, føle, sanse. Men det traditionelle begreb om bevidnelse eller, med et latinsk ord, attestation, $\mathrm{fx}$ i forbindelse med en autobiografi, synes at udelukke både fiktion og kunst, når det skal handle om 'sandheden, hele sandheden og intet andet end sandheden' (jf. Derrida 1998: 51), idet fiktionen og det æstetiske antages at korrumpere og lede bort fra sandheden. Over for dette traditionelle begreb om bevidnelse er det altså Derridas tese, at ethvert ansvarligt vidnesbyrd involverer en poetisk erfaring af sproget, et æstetisk element. Dette hænger sammen med det autobiografiske, idet det er en del af sprogets essens - Derrida bruger selv denne for sin tænkning i øvrigt fremmede term i et interview med Evelyne Grossman (Derrida 2001: 85) - at sproget ikke lader sig appropriere. Sproget er netop det, der ikke lader sig besidde, og som af den grund fremprovokerer alle mulige appropriationsfors $\varnothing \mathrm{g}$.

Derrida hævder, at når jeg taler, i dette øjeblik (instant), et sprog, fx fransk eller dansk, er det et vidnesbyrd (Derrida 1998: 37f.). Idet jeg taler, bevæger jeg mig fra "jeg" til "du". Jeg taler - lad os oversætte Derrida fra fransk og sige - dansk og antager dermed, at nogen er i stand til at forstå dette sprog, og dermed i stand til at danne et "vi" med den, der i dette øjeblik taler, det vil sige med mig (jeg tager nu Derridas eller i det mindste det franske "je's" plads). ${ }^{\text {II }}$ Vi er altså øjeblikkeligt mere end én, så snart jeg eller et "jeg" taler. ${ }^{12}$ I og med, at jeg aktualiserer sproget, det danske, antager jeg nødvendigvis, at nogen - om ikke i den aktuelle situation, så i hvert fald i princippet - vil kunne forstå, hvad jeg siger, og dermed også vil kunne danne et "vi" sammen med mig, at nogen faktisk vil forpligte sig til at danne et "vi" med mig, at nogen vil svare, at nogen vil være ansvarlig. Dette ubestemte "vi" er ifølge Derrida en betingelse for vidnesbyrdet, ikke forstået sådan, at det forudsætter en enighed i det, jeg siger, en sympati eller nogen form for konsensus, men blot "en minimal måde at være, lad os sige en forståelse med den anden, sammen med mig her i sproget i det øjeblik, hvor det tales, hvor det er talt" (38). Implikationen 
af et "vi", forstået som delingen af et bestemt sprog, et idiom, og det fælles ansvar for sproglig kompetence, "vidner om en essens i vidnesbyrdet" (39), da der ikke ville kunne være nogen bevidnelse uden. Dette at bevidne, at bære vidnesbyrd, kræver en talehandling, og derfor at nogen antages at kunne bemestre sproget $i$ et vist omfang. På den anden side kræver bevidnelsen en adressat, der også kan bemestre sproget i et vist omfang og dermed forstå det, der siges, og som på sin side siger "vi", uanset om hun tror på eller er enig i udsagnet, i indholdet i det, der siges. For at kunne begynde at anfægte rigtigheden af en bevidnelse må man først have forstået den, ligesom man må være sikker på at kunne skelne mellem et vidnesbyrd og en vidnesbyrdfiktion, dvs. mellem en seriøs, oprigtig og edsvoren diskurs og en diskurs, som lyver og blot foregiver at fortælle sandheden, at tale under ed, enten for at bedrage eller for at frembringe litteratur (35-36). Meneden, løgnen, bedraget, det falske vidnesbyrd bryder med "vi'et", men forudsætter alligevel stadig, at vi kommunikerer og taler det samme sprog. Jeg kan ikke lyve for nogen, der ikke forstår mig, med hvem jeg ikke har en fælles forståelse.

Vidnesbyrdet er altså altid autobiografisk, altid en handling i førsteperson: "Vidnesbyrdets essens lader sig ikke nødvendigvis reducere til fortællingen, dvs. til beskrivende, informative forbindelser, til viden eller til beretning; det er først og fremmest en nærværende handling." (44). Denne nærværende handling er et fors $\varnothing g$ på at gentage et andet, tidligere nærvær, nemlig vidnets sanselige nærvær over for det, der efterfølgende søges bevidnet og kommunikeret til en anden vidnet har overlevet det, der bevidnes, vidnet er en overlevende, superstes. I sin læsning af Paul Celan (Derrida 2005: 32-36), hævder Derrida, at det, når jeg "bærer vidne", betyder, at jeg sværger, at jeg så, hørte, mærkede, lugtede, at jeg var til stede. Vidnesbyrdet har således en uomgængelig præsentisk sanseperceptuel dimension, en sanseperceptuel tilstedeværelse eller nærvær eller havende været nærværende: Dette var nærværende for mig i tid og rum, du må tro mig, jeg siger dig sandheden. Den, som vidnet henvender sig til, har ikke umiddelbar adgang til vidnesbyrdets genstand, til det vidnet har erfaret. Det bevidnede, genstanden, er fraværende, og dette fravær er ifølge Derrida - med den for hans tænkning ellers uvante, men her altså for fjerde gang anvendte term - essentielt. Det knytter sig til vidnesbyrdets tale, for så vidt sproget kan adskilles fra det, det bevidner. For vidnet er heller ikke længere nærværende, det vil sige præsentisk nærværende, over for det, hun erindrer, forstået på den måde, at hun ikke kan percipere det sanseligt. I det øjeblik, hun begynder at bære vidnesbyrd, er hun ikke længere nærværende over for det, hun siger, hun var nærværende overfor, det, hun siger, hun sansede, idet erindringen om det nu artikuleres gennem sproget - hun er nu overlevende og præsenterer, i vidnesbyrdet, sin havende-været-nærværende. Vidnesbyrdet, at bære vidne, er en handling, som manifesterer sandheden, hvilket vil sige, at det er en gentagelse af det, der er eller var nærværende. At bære vidne er derfor ikke det samme som at føre bevis. Den, der bærer vidne, tilvejebringer intet bevis, men er én, hvis i princippet singulære og uerstattelige, ikke-substituérbare, erfaring bevidner eller attesterer - jf. de latinske betegnelser for vidne: testis og superstes (jf. Benveniste: 276f.) - at noget har været nærværende for hende. Dette noget er naturligvis ikke længere perceptuelt nærværende for hende, når bevid- 
nelsen finder sted, men det er nærværende for hende som det, der nu re-præsenteres i erindringen. ${ }^{\mathrm{I} 3}$

Det, der ifølge Derrida adskiller en vidnesbyrdhandling fra en simpel vidensoverførsel, en simpel information eller demonstrationen af en allerede bevist teoretisk sandhed, er altså, at nogen engagerer og forpligter sig i forhold til en anden (jf. Derrida 2005: 45f.). Dette engagement sker gennem en om ikke eksplicit så i al fald implicit ed. Den, der bærer vidne, lover at sige noget til eller manifestere noget for den anden, den som hun henvender sig til. Det, hun siger eller manifesterer, er en sandhed, noget der enten har været eller er nærværende for hende som et unikt, sansende og uerstatteligt vidne. Vidnets egenskab af uerstattelig singularitet betyder, at den modtagende ikke har andet valg end at tro eller ikke at tro det, der bevidnes af vidnet. Verifikation og bevisførelse, etablering af 'sikker viden' er derfor fremmed for vidnesbyrdet - så snart det er garanteret og sikret som teoretisk bevis, kan det ikke længere være garanteret som vidnesbyrd (Derrida 2005: 14). Vidnesbyrdet står alene og uden bevis og kan således ikke autoriseres via en tredje part eller via en andens vidnesbyrd. Der er ikke et andet vidne for vidnet - "Niemand zeugt für den Zeugen," "Ingen vidner for vidnet," som det hedder i den berømte slutstrofe i Paul Celans digt "Aschenglorie" fra 1967, som Derrida læser og udfolder i Poétique et politique du témoignage.

Umuligheden af at erstatte vidnet forbinder vidnesbyrdet med en art hemmelighed, en hemmeligholdelse. At bære vidne er ifølge Derrida altid forbundet med en erfaring af noget hemmeligt. Hemmeligheden er vidnets privilegium, hendes særrettighed, idet hun ikke kan erstattes af en anden, da hun essentielt ("par essence" - det er, som allerede bemærket, påfaldende hvor ofte forskellige former af 'essens' optræder i Derridas behandling af vidnesbyrdets fænomenologi) er den eneste, som kan vide, hvad hun har erfaret, sanset, set, hørt, følt, lugtet etc. ${ }^{14}$ Det er derfor, den modtagende, adressaten, må tro på det, hun siger, når hun forsøger at kommunikere og publicere sin singulære hemmelighed, som ikke desto mindre samtidig forbliver hemmelig; hemmeligheden fremstår som hemmelig (jf. Derrida 2005: 60f.).

Et af de grundliggende træk, der kendetegner fiktion, er, at den skaber sin egen reference, mens vidnesbyrdet udmærker sig ved at referere til datoer, begivenheder og erfaringer, det ikke selv frembringer (som det tilsyneladende er tilfældet med Blanchots brev fra 1994 til Derrida), men som det tværtimod fors $\varnothing$ ger at bevidne. Det betyder, at der i vidnesbyrdet er en særlig forpligtethed på sandheden og på en singulær begivenhed, der faktisk har fundet sted, før den søges repræsenteret i vidnesbyrdet. Der er altså tale om en singularitet, der skal kommunikeres - og det er i selve denne deling og gentagelse, denne kommunikation, at fiktionen og litteraturen trænger sig på. Vidnesbyrdet er som nævnt netop ikke blot bevisførelse, men en bevidnelse eller attestation af noget, der har været nærværende for den, der bærer vidnesbyrdet, det vil sige den, der erindrer det og re-præsenterer det gennem en sproglig artikulation.

Som Peggy Kamuf bemærker, må vidnesbyrdet for at være et vidnesbyrd snarere end et bevis indeholde muligheden for at være falskt, det vil sige en fiktion, men fiktionen skal i Derridas tænkning ikke kun forstås som det sandfærdiges modsæt- 
ning. Den litterære fiktion og det poetiske kommer, modsat hvad det traditionelle begreb om bevidnelse tilsiger, til at udgøre det eksemplariske sted for vidnesbyrdet og refleksionen over det (Kamuf: 889) - hvorfor også ethvert ansvarligt vidnesbyrd som nævnt indledningsvist antages at involvere en poetisk erfaring af sproget. At litteraturen og poesien er 'eksemplarisk' skal forstås Derridask, eller med en af hans arvtagere (de to tænkeres store forskelle og uenigheder i øvrigt ufortalt), Giorgio Agamben:

4 Det [eksemplet] er en singularitet blandt andre, men det står dog i stedet for hver af dem, det gælder for dem alle. På den ene side bliver hvert eksempel faktisk behandlet som et reelt partikulært tilfælde; på den anden side bevares forståelsen af, at det ikke kan være gyldigt i sin partikularitet. Hverken partikulært eller universelt, eksemplet er et singulært objekt, der så at sige viser sig frem som sådant, det viser sin singularitet. (Agamben: in press)

Blanchots og Celans litterære og poetiske vidnesbyrd er eksemplariske, fordi de ikke blot fungerer som eksempler på eller illustrationer af noget allerede foreliggende og for vidnesbyrd generelt gældende, men også hver især udgør singulære, eksemplariske vidnesbyrdhandlinger. Som førnævnte Kamuf skriver, må ethvert vidnesbyrd være eksemplarisk i begge disse betydninger: på én gang kommunikerende, erstatteligt, gentageligt, oversætteligt, generalisérbart, universalisérbart og hemmeligt, uerstatteligt, ugentageligt, uoversætteligt, singulært. Vidnesbyrdets betingelse er derfor simpelthen denne, at det singulære må være universalisérbart. I en logik, der minder om Kants analyse af smagsdommens kvantitative moment og den heri beskrevne af interesseløshed tilvejebragte subjektive almengyldighed (jf. Kant: §§ 6-9 og Wallenstein) samt den hermed forbundne forestilling - i analysen af det fjerde moment, modalitet - om en sensus communis, det vil sige en universel fælles evne til at nå til forståelse og enighed, en fællesmenneskelig evne til at have følelser til fælles (Kant: §§ 20-22 og 40), beskriver Derrida det således:

4 Når jeg siger: Jeg sværger at sige sandheden dér, hvor jeg har været den eneste til at se eller høre, og hvor jeg er den eneste, som kan bevidne det [sete eller hørte], er det sandt for så vidt, at enhver i mit sted, i dette øjeblik [instant], ville have set eller hørt eller rørt den samme ting og eksemplarisk, universelt, ville kunne gentage mit vidnesbyrds sandhed [...] Det singulære må være universalisérbart, dette er betingelsen for vidnesbyrdet [la condition testimoniale]. Simultant, i samme øjeblik, hævder jeg, kræver jeg, postulerer jeg i sætningen 'jeg sværger, du må tro mig' den mulige og nødvendige universalisering af denne singularitet: Enhver $i$ mit sted etc., ville bekræfte mit vidnesbyrd, som således på én gang er uendeligt hemmeligt og uendeligt offentligt; og det er derfor, jeg i forvejen indlader mig på at gentage, og jeg begynder ved at gentage. Det, jeg siger for første gang, er, hvis det er et vidnesbyrd, allerede en gentagelse, i det mindste en gentagelighed. (Derrida 1998: 47f.)

Det komplekse og problematiske forhold mellem singularitet og gentagelighed eller iterabilitet og dermed universalisérbarhed trænger sig naturligvis især på i forhold 
til Auschwitz og Holocaust, hvis unikke singularitet udgør et af de vigtigste omdrejningspunkter i de erindringskulturelle og erindringspolitiske diskussioner. Om sit forhold til Auschwitz siger Derrida i et interview på engelsk:

6f The thought of the incineration of the holocaust, of cinders, runs through all my texts. [...] What is the thought of the trace, in fact, without which there would be no deconstruction? [...] The thought of the trace [...] is a thought about cinders and the advent of an event, a date, a memory. But I have no wish to demonstrate this here, the more so, since, in effect, 'Auschwitz' has obsessed everything that I have ever been able to think, a fact that is not especially original. Least of all does it prove I have ever had anything original or certain to say about it (Derrida 1992a: 211-212).

Derrida mener altså, at "Auschwitz" har indvirkning på hele hans tænkning, men hævder ikke at have haft noget originalt eller endeligt afklaret at sige om begivenheden, men netop hans tanker om vidnesbyrdet - der i læsningen af Blanchot dog kun indirekte vedrører Auschwitz - og dets kommunikation synes at udgøre et betydeligt bidrag til "Auschwitz-tænkningen". ${ }^{5}$ I parentes bemærket er Derridas tænkning i det hele taget ikke blot i sit indhold, men især også i sin prøvende, spørgende form en tænkning 'efter Auschwitz'. ${ }^{16}$ Derrida fremhæver, at det er Adornos unægtelige fortjeneste at have vækket så mange tænkere, forfattere, undervisere og kunstneres ansvarsfølelse i forhold til alt det, for hvilket Auschwitz må forblive både det uerstattelige egennavn og en metonymi (jf. Derrida 2001: 78); han markerer altså på én gang Holocausts singularitet, eksemplificeret med Auschwitz, og en bredere forståelse af menneskelig lidelse.

Forholdet mellem singularitet og gentagelighed, mellem begivenheden og dens italesættelse eller kommunikation er et af de mest gennemgående og centrale spørgsmål i Derridas tænkning. Om forsøget på at sige en historisk begivenhed, som den finder eller fandt sted, det vil sige om forsøget på en "sigen af begivenheden som sigen af viden eller information", skriver han:

6f Denne sigen af begivenheden er på sin vis altid problematisk, da "sigen" i kraft af sin struktur kommer efter begivenheden. På den anden side, da den som sigen og dermed sproglig struktur er forbundet med en vis generalitet, en vis iterabilitet, en vis mulighed for gentagelse, vil den altid mangle begivenhedens singularitet.

En af begivenhedens egenskaber er ikke blot, at den kommer som det uforudsigelige, det, der opbryder historiens normale gang, men det er også, at den er absolut singulær. At sige begivenheden, sigen som viden om begivenheden, mangler på sin vis a priori fra begyndelsen begivenhedens singularitet af den simple årsag, at den kommer efter og taber singulariteten i en generalitet. (Derrida 2009: 13)

Selve italesættelsen eller sprogliggørelsen indebærer uvægerligt et singularitetstab. Sproget fungerer i kraft af en iterabilitet, en gentagelighed, af at det betegnede er erstatteligt, substituérbart. Vi forstår kun ordene, fordi de er gentagelige; vi genkender dem, hvilket betyder, at originaliteten udviskes af gentageligheden. Men på den anden side er dette den eneste måde, begivenheden bliver tilgængelig for os, den 
eneste måde hvorpå den kan deles, kommunikeres: "Ligeledes kan begivenheden kun fremstå som sådan, hvis den i selve sin originalitet er gentagelig" (ibid.). ${ }^{17}$ Vidnesbyrdet implicerer muligheden for fiktion og løgn, for litteratur, i selve sin struktur. Hvis denne mulighed, som vidnesbyrdet ellers umiddelbart burde udelukke, ikke var til stede, ville der være tale om bevis og sikker viden, og det ville ikke længere fungere som vidnesbyrd. For at forblive vidnesbyrd må det lade sig hjemsøge af muligheden for at være litteratur (jf. Derrida 1998: 31). ${ }^{\mathrm{I}}$ Det er, blandt andet, dét, Derrida lærer os gennem sin læsning af Blanchots L'Instant de ma mort.

Tak til Mikkel Bolt for kommentarer til teksten.

\section{Noter}

I Se Gregory Ulmer: Applied Grammatology (1985) for et relativt tidligt forsøg på at redegøre for dekonstruktionens, eller i hvert fald den heraf grundlæggende grammatologis, anvendelighed.

2 Hvor intet andet fremgår, er oversættelser mine.

3 Se også Mikkel Bolt: “Ja, selvfølgelig, men...” i nærværende nummer af Passage for en analyse af Derridas politiske reservation over for traditionelt politisk engagement.

4 Fichus er som nævnt skrevet i anledning af, at Derrida den 22. september 2001 modtog Adornoprisen. Et andet træk, der kendetegner den sene Derrida, er måske hans mere åbenlyse vedgåelse af sin gæld og affinitet til Adorno. Ud over de punkter, Derrida opridser i Frankfurt-talen, synes de to tænkere især at mødes i tænkningen af "det ikke-identiske" og "det ikke-begrebslige" (se Sven-Olov Wallensteins artikel “Æstetikkens ramme: Derrida, Kant og det parergonale” i dette nummer af Passage vedrørende disse fænomener i Derridas æstetiske tænkning).

5 "Le parjure" behandles mere indgående i Hans Hauges artikel "Anakoluthon: Fortælling og løgn" i dette nummer af Passage.

6 Derrida citerer - hvilket han aldrig før i sit liv har vovet at gøre, men som han gør, fordi han finder det nødvendigt for at kunne lave den læsning, han gerne vil, det vil sige for at kunne sætte et tilsyneladende ikke-litterært og ikke-fiktivt vidnesbyrd i forbindelse med et vidnesbyrd, der præsenteres som litteratur - et personligt brev, som han modtog fra Blanchot et år tidligere (det vil sige i 1994), hvori denne skriver: "20. juli. For halvtreds år siden, havde jeg den lykke næsten at blive henrettet.” (Derrida 1998: 64). Ifølge Derrida siger brevet, der altså ikke er litteratur, det samme som fiktionsteksten. Det vidner om virkeligheden af den begivenhed, som tilsyneladende udgør referenten for fiktionsteksten L'Instant de ma mort (ibid.: 65).

7 Teksten er oversat til dansk hele to gange. Første gang af Kim Su Rasmussen i Slagmark nr. 32, 2001, pp. 109-111, og anden gang af Carsten Madsen i Behrendt, pp. 330-334.

8 Se Bidents imponerende biografi for en afdækning af de autobiografiske elementer i teksten.

9 Se fx Rasmussen for en redegørelse for Blanchots højrenationalistiske fortid. Det skal dog retfærdigvis samtidig bemærkes, at Blanchot reddede sin nære jødiske ven, Emmanuel Levinas' familie under krigen ved først selv at skjule dem og senere skaffe dem ophold i et kloster frem til krigens slutning (Levinas er i øvrigt også af afgørende betydning for Derridas etiske tænkning, vedrørende denne se Henrik Skov Nielsens artikel "At give ret, ret at give" i dette nummer af Passage). Ved en stor Blanchot-konference i Paris 26.-29. marts 2003, Maurice Blanchot: Récits critique, fortalte Derrida, at han og Monique Antelme, enke efter Robert Antelme og præsident 
for l'Association des amis de Maurice Blanchot, havde henvendt sig til Gallimard med opfordringen om at udgive Blanchots œuvres complètes, men at Blanchots eget forlag ikke var interesseret grundet mange af teksternes 'manglende aktualitet'. Derrida mente, at det i virkeligheden var et udtryk for det velrenommerede forlags berøringsangst over for det tidlige, politisk angribelige materiale. Bidragene fra konferencen - herunder Derridas "Maurice Blanchot est mort", hvor han bl.a. igen behandler L'instant de ma mort - er publiceret i Bident \& Vilar.

Io På dansk beskæftiger eksempelvis Behrendt sig med Derridas læsning af det, der hos ham forstås som Blanchots "dobbeltkontrakt" (Behrendt: 328-352).

II Det er blandt andet også det, Derrida lærer os eller provokerer os til: at dramatisere os selv, at sætte vores egen subjektivitet i og på spil. Se blot på bidragene til dette nummer af Passage.

I2 Jf. min bog Den subjektive rest, pp. 31-35 samt note 25 pp. 62-63 for en redegørelse for talens implicering af et "du" i relation til Émile Benvenistes udsigelsesteori.

I3 Det er netop spørgsmålet - hvilket Derrida naturligvis er sig pinligt bevidst - om sproget lader sig adskille fra det, det bevidner, jf. eksempelvis Andreas Huyssen: "[A]ll representation [...] is based on memory. Re-presentation always comes after, even though some media will try to provide us with the delusion of pure presence. But rather than leading us to some authentic origin or giving us verifiable access to the real, memory, even and especially in its belatedness, is itself based on representation. The past is not simply there in memory, but it must be articulated to become memory." (2-3).

I4 Vedrørende hemmeligholdelsen, jf. eksempelvis Karin Gundersens artikel "Dyret i dekonstruktionen" i nærværende nummer af Passage.

I5 Se Eaglestone 2002 og 2008 vedrørende Derrida, den dekonstruktive tænkning og arven fra Holocaust.

I6 Jf. Adornos (forsøg på en) forståelse af Samuel Becketts værk som et værk, der hæver sin kritik til formens niveau, idet det lader formen indhente indholdet og forandre det, og dermed åbner et sted for andetheden og ikke-identiteten (Adorno).

I7 Vedrørende "vidnesbyrdets kommunikation" se også min artikel med denne titel (Lund 2009).

I8 Se Stefan Iversens og Lilian Munk Rösings artikler i dette nummer af Passage vedrørende hjemsøgelsesfiguren.

\section{Litteratur}

Adorno, Theodor (1990): "Fors $\varnothing$ g på at forstå Slutspil" ["Versuch, das Endspiel zu verstehen”, 1961], oversat af Frederik Tygstrup, in: Peter Madsen \& Helge Rønning (red.), Litteratur og modernitet, København: Tiderne Skifter, pp. 226-260.

Agamben, Giorgio (2009): "Eksempel" ["Esempio", 1990], oversat af Mads N. Outzen, in: Mikkel Bolt \& Jacob Lund (red.): Fællesskabsfølelser, Århus: Klim (in press).

Behrendt, Poul (2006): Dobbeltkontrakten: En æstetisk nydannelse, København: Gyldendal.

Benveniste, Émile (1969): Le Vocabulaire des institutions indo-européennes, 2: Pouvoir, droit, religion, Paris: Editions de Minuit.

Bident, Christophe (1998): Maurice Blanchot: Partenaire invisible, Seyssel: Éditions Champ Vallon. Bident, Christophe \& Pierre Vilar, red. (2003): Maurice Blanchot: Récits critique, Paris: Farrago \& Léo Scheer.

Blanchot, Maurice (1994): L'Instant de ma mort, Montpellier: Fata Morgana.

Bolt, Mikkel (2009): “Ja, selvfølgelig, men...”, in: Passage nr. 61.

Derrida, Jacques (1992a): "Canons and Metonymies: An Interview with Jacques Derrida", in: Richard 
Rand (red.): Logomachia: The Contest of the Faculties, London: University of Nebraska Press, pp. 195-218. Derrida, Jacques (1992b): “This Strange Institution Called Literature' An Interview with Jacques Derrida", in: Jacques Derrida: Acts of Literature, Derek Attridge (red.), New York \& London: Routledge, pp. 33-75.

Derrida, Jacques (1998): Demeure - Maurice Blanchot, Paris: Galilée.

Derrida, Jacques (2001): “La langue n'appartient pas”, Entretien avec Jacques Derrida réalisé par Evelyne Grossman, in: Europe “Paul Celan”, Jan.-Fev., nr. 861-862, pp. 81-91.

Derrida, Jacques (2002a): Fichus, Paris: Galilée.

Derrida, Jacques (2002b): "Le parjure, peut-être ('brusques sautes de syntaxe')", in:Études françaises vol. 38, nr. 1-2, pp. 15-57.

Derrida, Jacques (2003): Voyous, Paris: Galilée.

Derrida, Jacques (2005): Poétique et politique du témoignage, Paris: L’Herne.

Derrida, Jacques (2009): "En vis umulig mulighed for at sige begivenheden" ["Une certaine possibilité impossible de dire l'événement", 2001], oversat af Torsten Andreasen, in: Passage nr. 61.

Eaglestone, Robert (2002): "Derrida and the Holocaust: a commentary on the philosophy of cinders", in: Angelaki 7:2, pp. 27-38.

Eaglestone, Robert (2008): "Derrida and the legacies of the Holocaust", in: Simon Glendinning \& Robert Eaglestone (red.): Derrida's legacies: literature and philosophy, London \& New York: Routledge, pp. 66-75.

Gundersen, Karin (2009): "Dyret i dekonstruktionen”, in: Passage nr. 61.

Hauge, Hans (2009): “Anakoluthon: Fortælling og løgn”, in: Passage nr. 61.

Huyssen, Andreas (1995): Twilight Memories: Marking Time in a Culture of Amnesia, New York: Routledge.

Iversen, Stefan (2009): “Besværgelser”, in: Passage nr. 61.

Kamuf, Peggy (2006): “Composition Displacement”, in: MLN nr. 121, pp. 872-892.

Kant, Immanuel (1995): Kritik der Urteilskraft [1790], Stuttgart: Reclam.

Lund, Jacob (2009): "Vidnesbyrdets kommunikation”, in: Mikkel Bolt \& Jacob Lund (red.): Fællesskabsfølelser, Århus: Klim (in press).

Lund Pedersen, Jacob (2008): Den subjektive rest: Udsigelse og (de)subjektivering i kunst og teori, Århus: Aarhus Universitetsforlag.

Nielsen, Henrik Skov (2009): “At give ret, ret at give”, in: Passage nr. 61.

Rasmussen, Kim Su (2003): Maurice Blanchot: Fra nationalisme til neutralitet, upubliceret ph.d.afhandling, Institut for Idéhistorie, Aarhus Universitet.

Rösing, Lilian Munk (2009): “Den sene Derrida, eller: Er Claus Beck-Nielsen et spøgelse?”, in: Passage nr. 61.

Wallenstein, Sven-Olov (2009): “Æstetikkens ramme: Derrida, Kant og det parergonale”, in: Passage nr. 61. 